\title{
Defending Jewish Identity and Culture in Malamud's Three Novels
}

\author{
Fang Xiang ${ }^{1}$ \\ ${ }^{1}$ School of Foreign Languages and Cultures, LeShan Normal University, LeShan, Sichuan Province, China \\ Correspondence: Fang Xiang, No. 402, Unit 2, Jin Ling, Man Ting Fang, No. 778, Xiaoba Road, LeShan City, \\ Sichuan Province, China.
}

Received: September 28, 2018 Accepted: November 13, 2018 Online Published: November 28, 2018

doi:10.5539/ells.v8n4p66

URL: https://doi.org/10.5539/ells.v8n4p66

\begin{abstract}
Malamud's novels are featured by the Jewishness. This thesis tries to analyse three characters' deviation from Jewish identity and culture, and their returning to the Jews or their awakening of Jewishness after they underwent despair and frustration in their life. This thesis also reveals Malamud's sarcasm toward those who betrayed Jews and his effort to defend Jewish identity.
\end{abstract}

Keywords: Jewish identity, Jewishness, deviation, defending

\section{Introduction}

Since Jewish people were expelled from their homeland after the second temple was destroyed by Romans army in 132 years, Jewish people began their arduous exile life and scattered in different countries in the world. Jewish history in fact is a history full of persecution, exclusion, massacre, fear, and exile. Twice massacre of Jewish people in the history left Jewish people in constant fear and indelible traumas in their mind. The hatred and discrimination toward Jewish people resulted in their miserable life, like unable to find a job, being excluded from some decent occupation, confined to live in ghettos. And even in some literature, Jewish characters were defamed. In Shakespeare, Mark twain, and Dickens' novels, Jewish people were depicted as the most voracious usurers, or vicious criminals. And thus Jewish people were persecuted or excluded wherever they went, so in order to protect themselves, they had to hide their Jewish identity, refuse to join in some Jewish group, or change their clothes or life habits in order to blend into the new society. To those second Jewish immigrants, owning to living in other countries for a long time, they not only cast the life style of Jewish people, like the clothes, religious rituals and eating habits, but also chose intermarriage which further destroyed Jewish culture and blurred the Jewish identity. Malamud's novels are typically featured by Jewishness or Jewish culture. In his three novels The Fixer, The Assistant, and The Lady of The Lake, traumas brought by massacre still hang over the Jewish people, which led to the young Jewish people's intended detaching from Jewish identity and culture.

\section{Abandonment of Jewish identity and Deviation from Jewish Culture}

The Judaism reflected in the self-deprecation of Jewish humor and pervasive not only in Yiddish literature but also in the fiction of Jewish-American writers, is clear: affliction and disaster are necessary to prove uniqueness and to reinforce the idea of closeness. Theology and experience compel Jew to deal with the disparity between ideal and the actual and the contradictions arising from the union of God's Promise with the reality of the ghetto, in a world where the possibilities of redemption are everywhere and fulfillment nowhere. (Alter, 1981, p.155) Just like Yakov in the Fixer who was defeated by his life, therefore lost confidence in the Judaism and decided to live the ghetto.

First, Yakov in The Fixer is a Jewish young man who suffered a lot in his miserable life, his parents died early, he didn't have a child, his wife left him, and he led an impoverished life. He ascribed his tragedy to Jewish history and Jewish identity, so in order to change his bad luck, he tried to abandon Jewish culture and Jewish identity. To Yakov, Jewish identity only brought him troubles and miseries. His estrangement from Jewish people was first manifested in his act to cut his beard which was regarded as a characteristic of the Jews. His father-in -law Shmuel scolded him “cut off your beard and you no longer resemble your creator". Shmuel was faithful to God and Jews, so he warned Yakov his behavior separated him from his people. His deviation from his people was also revealed in his decision to leave the town which was inhabited by the Jews for Kiev to look for good luck. "The shtetl is a prison, no change from the days of Khmelnitsky. It moulders and the Jews moulder in it. Here we're all prisoners, I don't have to tell you, so it's time to try elsewhere I've finally decided. I want to make 
a living. I want to get acquainted with a bit of the world (Malamud, 1966, p. 14). Escaping from Shtetl meant a change of his life which also showed his uncommitment to Jews. But Shmuel also warmed him of the danger of leaving Jews congregation, and told Yakov"a Jews can see the tree and mountain of Jews, inhale Jewish air; if I had half a chance there's where I'd go" (Malamud, 1966, p. 14). Before Yakov departed, Shmeul gave him a shawl and a Bible which meant to remind Yakov of God and Jewishness. To Yakov, God never favored the Jews. "He's with us till the Cossacks come galloping, then he's elsewhere. He's in the outhouse, that where he is" (Malamud, 1966, p. 14). "We live in a world where the clock ticks fast while he's on his timeless mountain staring in space. He doesn't see us and he doesn't care. Today, I want my piece of bread, not in Paradise" (Malamud, 1966, p. 19). At the beginning, Yakov, different from his father-in-law who was faithful to Jewism, decided to look for his freedom and a good life by escaping to Kiev. Keeping away from Jewish culture is a way for Yakov to pursue a new life and happiness. When he was on the boat, the crew's hatred toward Jewish people startled and frightened him, his stealthily throwing Bible into river further demonstrated his abandonment of the Jewish culture for his safety. Ironically, when he arrived at Kiev, he saved an old man who wore Double Eagle emblem of the virulently anti-Semitic organization, Black Hundreds. For survival, he even concealed his Jewish identity and accepted the old man's offer working in his factory which excluded the Jewish people. Did Yakov's abandonment of Jewish identity win him good luck and a better life? On the contrary, leaving ghetto brought him strangeness, and concealing his identity for survival left him in constant fear and panic, so eventually he couldn't escape his fate as a Jew. What's more, the catastrophe fell on him because he was even charged with the crime of killing one Christian boy whose blood was used to make bread for Pesach in Jew's ritual and thus he was put into prison. In prison, he admitted his Jewish identity and claimed he was a man free of Jewish religion and his innocence, but he found he couldn't escape this disaster because of Jewish identity. The idea that concealing the Jewish identity, and detaching himself from Jewish people could change a Jew's fate was just an illusion.

In Malamud's another short story The Lady of The Lake, the protagonist Freeman, the second American Jewish immigrants also intended to conceal his Jewish identity. First, Freeman changed his name from Henry Levin to Henry R.Freeman, for he thought the change of his name would help him shake off the Jewish identity for real freedom which is the true meaning of the name. When Freeman travelled in Italy, he met a lovely girl Isabella who inquired whether he was a Jewish man. To Freeman, Jewish identity just meant a disgraceful past, pains, contempt, and Jewish people were always misunderstood as vicious and greedy. Afraid of being refused by Isabella because of his Jewish identity, he denied his real identity. His lie didn't relieve him from the burden brought by Jewish identity, for he had to find out another way to hide the truth, like changing his family name. But in fact, changing his family name would bring other dilemmas to him, which meant his abandonment of his ancestors and his past, and he also felt regretful for his parents. Freeman's attitude toward his Jewish identity implied his distancing himself from Jewish history and Jewish people. When one was separated from one's people and history, he became homeless wherever he went, he couldn't find comfort or satisfaction. Just like Freeman, wherever he went, he couldn't feel satisfied. When he found his lover, he was plunged into another dilemma because of his denying of his past and identity.

In the short novel "The Assistant", Morris was a pious Jew who committed to the Jewish law which guided him to help other people as possible as he can or at the sacrifice of his own interest. But his daughter Helen, the second immigrant showed different attitude toward Jewish culture. First Jewish law prohibits any intermarriage. But Helen hold a different attitude toward the marriage concept. Helen refused the proposal of her friend Lewis and the love of Tina, both of whom were Jews. Though two of them were Jews, but Helen found it hard to accept their love or proposal, for she thought they had different value of life, and a happy marriage should be based on love, equality, and the same value and she wanted to pursue a better life through her hard working. Here Helen's value on marriage is influenced more by the American conception than that of Jews. She even considered having the same ideal, love and respect can guarantee a happy marriage rather than the same religion. Helen's concept on marriage showed the influence of Jewish culture on the second immigrants gradually faded away.

Helen's deviation from Jewish culture also embodied in her inquiry of her father's kind behavior. Morris committed to Jewish law, trying his best to help other people, but at last, he died of poverty, sadness, and illness. Just as Helen said, he sacrificed himself for others, but he was not saved by God.

\section{Defending Jewish identity and Culture}

The three novels showed the characters' abandonment of Jewish identity and attempting to forget Jewish culture for a better life, but finally they found abandoning Jewish identity would not promise them a good future, and at the same time, Jewish culture had taken root in their heart as a collective memory.

In order to change his life, Yakov left the ghetto and concealed his identity, but it's hard for him to cut off the 
relationship with the Jewish people. He acts against his own principles of non-commitment when he rescues an old Hasidic Jew from some boys and takes him in(Helterman, 1985, p.77). When he saw a Jewish old man being hit by some boys, injured and shedding blood, he felt disturbed and took the Jewish old man to his dorm where the Jewish man was excluded at the risk of exposing his identity. He helped the old man to wash the blood and bind up his wound. Yakov's help toward the Jewish old man showed his deep sympathy to the Jewish people, though he attempted to escape from the Jewish people and hide his Jewish identity, but Jewish emotion was embedded in his heart. "He said the blessing for matzos, and sighing, munched a piece. It came as a surprise to the fixer that it was Passover. He was moved by a strong emotion and had to turn away till it had gone" (Malamud, 1966, p. 62). When he saw the old man eating the matzos, he was reminded of the approaching of Passover and deeply touched by that.

Yacov believes that being uncommitted in everything can keep him out of trouble, when in fact commitment will become his only way to exist.(Helterman, 1985, p. 77) Yakov hided his identity by all means, but at last he was put into prison for he was charged with the crime of killing a Christian boy. At first, He innocently thought he could be released from the prison after he admitted his identity, because he was innocent. Two years of suffering and torturing made him realize that his release from prison seemed impossible, because he was taken as a scapegoat for the Jewish people, and this murdering was a conspiracy to slander the Jewish people with the horrible aim to launch another holocaust to the Jews made by those anti-semitism. Once he admitted it was he who committed the crime, he would bring great disaster to the Jewish people. Yakov's hiding of his identity failed to give him a better future, but further entangled him in a murder and endless suffering. Yakov's deep emotion toward the Jews prevented him from admitting the crime, and also gave him the courage and determination to protect the Jews. Yakov gradually found that his abandonment of Jewish identity couldn't change his fate, only when he really identified himself with the Jewish people and fought with them for freedom, they could ultimately change their fate. "Those Jews who escape with their lives live in memory's eternal pain. So what can Yakov Bok do about it? All he can do is not make things worse. He's half a Jew himself, yet enough of one to protect them. After all, he knows the people; and he believes in their right to be Jews and live in the world like men. He is against those who are against them. He will protect them to the extent that he can. This is his covenant with himself. If God's not a man he has to be" (Malamud, 1966, p. 246).

In The Lady of the Lake, in order to start a new life and win Isabella's love, Freeman denied his Jewish identity. But ironically, his denying on the contrary shattered his dream. To Freeman's great surprise, it turned out that Isabella was a Jew. And what's more, Isabella's attitude had a great contrast with that of Freeman. Isabella suffered from the massacre which left an indelible stamp on her body and her mind, but she never escaped from this trauma. When Freeman proposed to her, she deliberately put off her clothes. "to his honor, he discerned tatooed on the soft and tender flesh a bluish line of distorted numbers." "I can't marry you. We are Jews. My past is meaningful to me. I treasure what I suffered for" (Malamud, 1962, p. 132). Isabella treated the horrible and bloody history through the way of remembering but not escaping or forgetting. Isabella cherished that part of history, and through remembering that history, Isabella defended the Jewish culture and history, realized her salvation, and relieved the trauma. On the contrary, Freeman chose forgetting and escaping from Jewish history, but his forgetting didn't bring him any happiness or real freedom, and he also lost the opportunity to win the love of Isabella. Through juxtaposing Isabella's attitude toward Jewish culture and that of Freeman, it shows it is impossible for a Jewish man to pursue his happiness or real freedom through abandoning his Jewish identity. The Jewish people's miserable history is a collective memory which is hard to be erased, and this history binds Jewish people together. Through Freeman, Malamud showed sarcasm toward those who deviated themselves from Jewish history.

In The Assistant, Helen was influenced by the Jewish culture when she was pursuing her marriage. She fell in love with Frank, but Frank was not a Jew. If she chose Frank, it meant she would go against Jewish law which didn't allow the intermarriage. "Although she had only loosely been brought up as Jewish she felt loyal to the Jews, more for what they had gone through than what she knew of their history or theology--loved them as a people, thought with pride of herself as one of them; she had never imagined she would marry anybody but a Jew. But she had recently come to think that in such unhappy times--when the odds were so high against personal happiness - to find love was miraculous, and to fulfill it as best two people could was what really mattered. Was it more important to insist a man's religious beliefs be exactly hers, or that the two of them have in common ideals, a desire to keep love in their lives, and to preserve in every possible way what was best in themselves" (Malamud, 1971, p. 160)? In Helen's inner heart, she loved the Jewish people because of their past history and the misery they underwent, and she was proud of being Jews. So she was tormented by this conflict. To a certain extent, Helen was somewhat influenced by the American concept which emphasized more on the individual 
happiness rather the commitment to a religion. As a Jew, Helen needed to commit to its law, but she found it hard for her to make a compromise between them. When Helen thought a happy marriage was based on the lovers' mutual idealism, and the same value, she decided to pursue the happiness in accordance with her true emotion, but not the law of Jew. From this aspect, it seems Helen deviated from Jewish culture. But at last when she found Frank didn't take the circumcision, she scolded him as a dog, and also left him firmly, which implied Jewishness as a collective memory had been deeply embedded in Jews' mind. Jews were affected by it deeply and unconsciously, and this memory and influence was eternal.

\section{Conclusion}

Yakov changed from abandoning Jewish identity to identifying with Jewish people, and even sacrificed his freedom for protecting Jews; To him, real freedom can only be achieved by fighting with Jews but not escaping; Ironically, Freeman discovered abandoning Jewish identity brought him endless disappointment, and Isabella realized her salvation through cherishing the Jewish history; Helen was tormented by the conflict of American conception and Jewish law, but she couldn't escape the Jewish emotion, and chose to commit to Jewish culture. The three novels shows the characters were in a dilemma of escaping the Jews identity or Jewish community, or in a conflict of struggling with the influence of its culture, but at last it turns out that Jewish history is a collective memory embedded in the blood of Jewish people, they couldn't abandon it or cut this relation, because they would be touched by it or influenced by it in a different way in different situation. Because of strong Jewish culture and spirit, Jews survived all those hardships, tortures, and traumas, they were bound together and defended Jews and Jewish identity in their own way.

\section{Acknowledgement}

This paper is supported by the grant of the Project of Sichuan federation of social science association: Study on Bernard Malamud's Works from the Perspective of New Historicism. Project No. (SC16XK10).

\section{References}

Alter, I. (1981). The Good Man's Dilemma. New York: AMS Press, INC.

Malamud, B. (1966). The Fixer. New York: Penguin Books.

Malamud, B. (1971). The Assistant. New York: Dell Publishing CO., INC.

Malamud, B. (1962). The Magic Barrel. Toronto: Ambassador Books, Ltd.

Hershinow, S. J. (1980). Bernard Malamud. New York: Frederick Ungar Publishing Co.

Helterman, J. (1985). Understanding Bernard Malamud. Columbia: University of South Carolina Press.

\section{Copyrights}

Copyright for this article is retained by the author, with first publication rights granted to the journal.

This is an open-access article distributed under the terms and conditions of the Creative Commons Attribution license (http://creativecommons.org/licenses/by/4.0/). 